\title{
Spectrophotometric Determination of Chromium as the Chromium-Peroxo-4-(2-pyridylazo)resorcinol Complex
}

\author{
William B. Ferng ${ }^{1}$ and Gordon A. Parker ${ }^{2, *}$ \\ 1 Dept. of Chemistry, Univ. of Michigan, Ann. Arbor, Michigan 48109, USA \\ ${ }^{2}$ Dept. of Chemistry, Univ. of Toledo, Toledo, Ohio 43606, USA
}

\section{Spektralphotometrische Chrombestimmung als Chrom-Peroxo-4-(2-pyridylazo)-resorcin-Komplex}

Zusammenfassung. Der ternäre Chrom-Peroxo-PARKomplex weist einen scheinbaren molaren Extinktionskoeffizienten von $62801 \cdot \mathrm{mol}^{-1} \cdot \mathrm{cm}^{-1}$ auf, wenn er aus $0,1 \mathrm{M}$ schwefelsaurer Lösung mit Ethylacetat extrahiert wird. Das Beersche Gesetz wird bis zu 6,0 $\mu \mathrm{g}$ $\mathrm{Cr} / \mathrm{ml}$ befolgt. Die Bedingungen für eine optimale Farbbildung, die Zusammensetzung des Komplexes, die Wirkung verschiedener Begleitionen und die Anwendung auf Stähle werden beschrieben.

Summary. The ternary complex chromium-peroxoPAR exhibits an apparent molar absorptivity of 62801 $\mathrm{mol}^{-1} \mathrm{~cm}^{-1}$ when extracted into ethyl acetate from $0.1 \mathrm{M}$ sulfuric acid solution. Beer's law is followed for solutions containing up to $6.0 \mu \mathrm{g} \mathrm{Cr} \mathrm{ml}{ }^{-1}$. Conditions for optimum color formation, complex composition, effects of diverse ions, and application to the determination of chromium in steels are described.

Key words: Best. von Chrom; Spektralphotometrie; Peroxopyridylazoresorcin-Komplex

Spectrophotometric determination of chromium(VI) as the familiar blue chromium-peroxo complex is well known $[3,9,10]$. The methods, however, lack sensitivity. To improve the detection limit while at the same time increasing the stability of the chromium-peroxo complex, attention was directed to the effect of complexation upon the spectrum of an auxiliary ligand. A procedure utilizing this approach with 2,2'-bipyridine has been reported [5]. In an attempt to further improve

* Address for correspondence the detection limit for chromium, additional ligands containing electron donating groups were studied. One of these PAR, 4-(2-pyridylazo)resorcinol, proved to be satisfactory. This paper describes optimum experimental conditions for the formation of a $1: 1$ adduct between the chromium-peroxo complex and PAR and its utility as an analytical procedure for chromium(VI).

\section{Experimental}

Reagents and Apparatus. All absorbance values were measured using a Cary Model 14 spectrophotometer with $1.00-\mathrm{cm}$ silica cells. A standard chromium(VI) solution $\left(25.0 \mu \mathrm{g} \mathrm{Cr} \mathrm{ml} l^{-1}\right)$ was prepared by dissolving dried, reagent-grade potassium dichromate, $\mathrm{K}_{2} \mathrm{Cr}_{2} \mathrm{O}_{7}$ in distilled deionized water. A $0.01 \%(w / v)$, aqueous solution of PAR, 4(2-pyridylazo)resorcinol, from Eastman Organic Chemicals was used without further purification. All other chemicals were of reagent grade quality.

Procedure. Transfer a sample aliquot, $1-10 \mathrm{ml}$ of solution containing up to $150 \mu \mathrm{g}$ chromium, to a $125-\mathrm{ml}$ separatory funnel. Add $1.0 \mathrm{ml}$ of $2.0 \mathrm{M}$ sulfuric acid and sufficient water to reach a final volume of about $20 \mathrm{ml}$. Add $20 \mathrm{ml}$ of ethyl acetate. Cool the funnel and its contents in an icewater bath at $10^{\circ} \mathrm{C}$ for $30 \mathrm{~min}$. All reagents added beyond this point are also cooled to $10^{\circ} \mathrm{C}$. Add $3.0 \mathrm{ml}$ of $3.0 \%$ (v/v) hydrogen peroxide. Shake the funnel vigorously for $30 \mathrm{~s}$, allow for layer seperation, and discard the aqueous phase. Add $10 \mathrm{ml}$ $0.01 \%$ (w/v) PAR. Again extract for $30 \mathrm{~s}$, allow for layer separation, and discard the aqueous phase. Transfer the organic phases to a $25-\mathrm{ml}$ volumetric flask, warm to room temperature, and add sufficient additional ethyl acetate to achieve a volume of exactly $25 \mathrm{ml}$. Measure the absorbance of this solution at $470 \mathrm{~nm}$ against a reagent blank prepared in the same manner but containing no chromium.

\section{Results and Discussion}

The absorbance spectrum of this complex (Fig. 1) exhibits a sharp peak at $470 \mathrm{~nm}$ and then quickly falls to zero absorbance at shorter wavelengths due to excess free PAR in the reference cell of the spectrophotometer. Molar absorptivity for the complex is $62801 \mathrm{~mol}^{-1}$ $\mathrm{cm}^{-1}$. Beer's law is obeyed up to a concentration of $6.0 \mu \mathrm{g} \mathrm{Cr} \mathrm{ml}^{-1}$. Optimum concentration for chromium, 


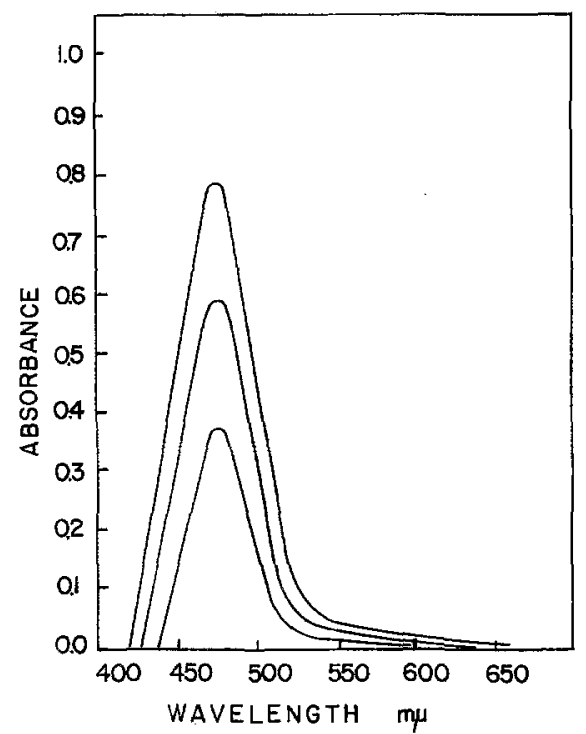

Fig. 1. Absorbance spectrum of chromium-peroxo-PAR complex in ethyl acetate, $7.0,5.0$ and $3.0 \mu \mathrm{g} \mathrm{Cr} \mathrm{ml} l^{-1}$ vs. a reagent blank

as determined by Ringbom's method [7] is 4.0 to $6.0 \mu \mathrm{g}$ $\mathrm{Cr} \mathrm{ml}{ }^{-1}$. Repetitive measurement, at $470 \mathrm{~nm}$ of twenty samples each containing $5.0 \mu \mathrm{g} \mathrm{Cr} \mathrm{ml}^{-1}$, resulted in a mean absorbance reading and standard deviation of $0.596 \pm 0.016$. The sensitivity index of this procedure, as

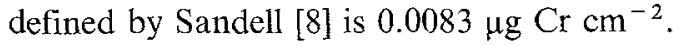

Optimum conditions for color development of the complex included a $0.1-0.3$ molar, sulfuric acid solution and addition of $2-3 \mathrm{ml}$ of $3 \%$ (v/v) hydrogen peroxide solution. The absorbance for the complex increases with increasing amounts of PAR. To avoid excessive PAR in the reference sample $10 \mathrm{ml}$ of $0.01 \%$ (w/v) PAR was selected. The chromium-peroxo complex itself is moderately stable in water solution at or below $10^{\circ} \mathrm{C}$ and at higher temperatures in the presence of an auxiliary ligand. It is essential that the sample solution and reagents be kept at $10^{\circ} \mathrm{C}$ when the chromium-peroxo complex is initially formed. The chromium-peroxo-PAR complex is sufficiently stable at ambient temperature for spectrophotometric measurements although readings should be made as soon as conveniently possible after the complex is formed. Absorbance values decreased by approximately $6 \%$ for samples which stood for $1 \mathrm{~h}$. Ethyl acetate is a suitable organic solvent for extracting the complex. No extraction took place when benzene, chloroform, cyclohexane, or hexane were used. Partial extraction occurred with methyl isobutyl ketone. Eighteen hiterto unreported ligands were studied as possible adducts. They are: aluminon, arsenazo III, benzoin $\alpha$-oxime, brucine, o-diaminobenzene, $p$ -

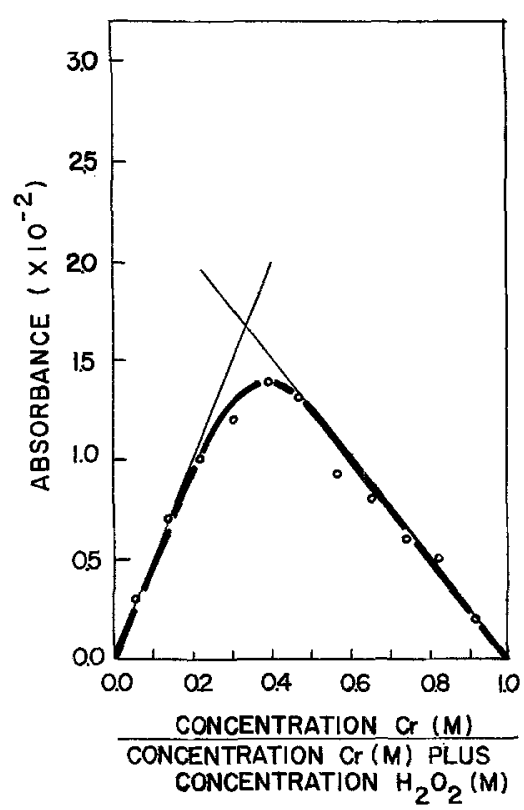

Fig. 2. Job's method for determining the ratio of chromium(VI) and peroxo groups, $[\mathrm{Cr}(\mathrm{VI})]+\left[\mathrm{O}_{2}^{2-}\right]=1.492 \times 10^{-4} \mathrm{M}, 10.0 \mathrm{ml} 0.01 \%$ $(\mathrm{w} / \mathrm{v})$ PAR in each sample

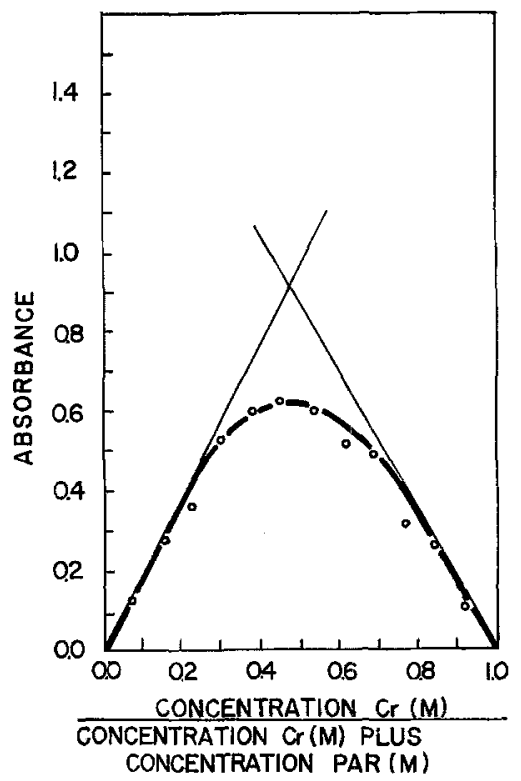

Fig. 3. Job's method for determining the ratio of chromium(VI) and PAR, $[\mathrm{Cr}(\mathrm{VI})]+[\mathrm{PAR}]=2.515 \times 10^{-4} \mathrm{M}, 3.0 \mathrm{ml} 3.0 \%(\mathrm{v} / \mathrm{v}) \mathrm{H}_{2} \mathrm{O}_{2}$ in each sample

diaminobenzene, dimethylglyoxime, 1,5-diphenylcarbohydrazine, eriochrome black $T, 8$-hydroxyquinoline, phenyl-2-pyridyl ketoxime, 3-(2-pyridyl)-5,6-diphenyl1,2,4-triazine, 1-(2-pyridylazo)-2-naphthol, 4-(2-pyridylazo)resorcinol, tetraphenylarsonium chloride, 2,2',2"'tripyridine, 2,4,6-tripyridyl-S-triazine, and zincon. PAR proved to be the most satisfactory ligand. 
Table 1. Standard steel samples

\begin{tabular}{llll}
$\begin{array}{l}\text { NBS } \\
\text { number }\end{array}$ & Type & $\begin{array}{l}\text { Chro- } \\
\text { mium (\%) } \\
\text { certified } \\
\text { value }\end{array}$ \\
& & \multicolumn{3}{c}{ This work $^{\mathrm{a}}$} \\
\hline $101 \mathrm{e}$ & $\mathrm{Cr}$ 18-Ni 9 (SAE 304) & 17.98 & $17.97( \pm 0.93)$ \\
$121 \mathrm{c}$ & Cr 18-Ni 10-Ti (SAE 321) & 17.58 & $16.70( \pm 0.17)$ \\
$30 \mathrm{~d}$ & Cr-V (SAE 6151) & 1.15 & $1.06( \pm 0.01)$ \\
139 & Cr-Ni-Mo (AISI 8640) & 0.549 & $0.406( \pm 0.015)$
\end{tabular}

a Mean of three determinations; range in parenthesis

Various diverse ions were added separately to a solution containing $5.0 \mu \mathrm{g} \mathrm{Cr} \mathrm{ml}^{-1}$ and the proposed determination performed. Interference was considered to occur if the absorbance differed from the expected value $(0.596)$ by more than 0.048 absorbance unit, i.e. three times the standard deviation for this amount of chromium. Barium, copper(II), iron(II), lead(II), manganese(VII), vanadium(V), iodide, cyanide, and oxalate ions must be absent from the sample solution. Interference from these ions occurs either through. precipitate formation, redox reactions with either chromium(VI) or hydrogen peroxide, or competing complexation reactions. Up to an 8-fold excess by weight of cobalt(II) or nitrate ion is acceptable. A 30fold excess of iron(III) is tolerable. Bismuth(III) or zinc are acceptable up to an 80-fold excess. A 120 -fold excess of nickel(II) is allowed. A 200-fold excess by weight of each of the following ions caused no interference: ammonium, aluminium, cadmium, calcium, lithium, magnesium, mercury(II), platinum(IV), strontium, thallium(III), tungsten(VI), uranium(VI), zirconium(IV), acetate, bromide, EDTA, fluoride, phosphate, and tartrate.

Because there is some controversy regarding the composition of the chromium-peroxo complex $[6,11]$ a study of the species formed under the conditions described was made. Job's method of continuous variation [4] was performed twice, first in the presence of a constant amount of PAR (to fix the $\mathrm{Cr}: \mathrm{O}_{2}$ ratio) and second in the presence of a constant amount of $\mathrm{H}_{2} \mathrm{O}_{2}$ (to fix the $\mathrm{Cr}$ :PAR ratio). Figure 2 illustrates the data for the chromium-peroxo ratio. Intersection of the extrapolated lines at 0.34 indicates a $\mathrm{Cr}: \mathrm{O}_{2}$ ratio of $1: 2$, respectively. This supports earlier studies for the chromium-peroxo complex as oxodiperoxochromium(VI) [2]. Figure 3 illustrates the data for the chromium-PAR ratio. Intersection of the extrapolated lines at 0.48 indicates a $\mathrm{Cr}: \mathrm{PAR}$ ratio of $1: 1$. This supports the contention of a 1:1 adduct between oxodiperoxochromium(VI) and a single electron pair donating ligand [1]. Thus the complex formed in this study is $\mathrm{Cr}(\mathrm{O})\left(\mathrm{O}_{2}\right)_{2}$ :PAR with chromium(VI) the central metal ion.

Following dissolution National Bureau of Standards, Washington, D.C., steel samples were analyzed by the proposed method. The results are shown in Table 1. Each of the first two samples, stainless steels, contained over $1 \%$ manganese, this appears to have some effect on the results. Titanium, approximately $0.4 \%$, also has a marked effect in the second steel. Manganese, when present in approximately equal amounts with chromium and vanadium causes some error in the $\mathrm{Cr}-\mathrm{V}$ steel. A 1.5:1 manganese to chromium ratio in the $\mathrm{Cr}-\mathrm{Ni}-\mathrm{Mo}$ steel makes the procedure unacceptable for chromium without prior separation.

\section{References}

1. Armstrong, R., Gibson, N. A.: Aust. J. Chem. 21, 897 (1968)

2. Connor, J. A., Ebsworth, E. A. V.: Adv. Inorg. Chem. Radiochem. 6, 280 (1964)

3. Glasner, A., Steinberg, M.: Anal. Chem. 27, 2008 (1955)

4. Job, P.: Ann. Chim. 9, 113 (1928)

5. Parker, G. A., Boltz, D. F.: Anal. Chem. 40, 420 (1968)

6. Rajput, B. S., Govil, P. K., Singhal, N. K. . J. Indian Chem. Soc. 48, 311 (1971)

7. Ringbom, R.: Fresenius Z. Anal. Chem. 115, 332 (1939)

8. Sandell, E. B., Onishi, H.: Photometric Determination of Traces of Metals. New York: Wiley-Intersci. 1978

9. Sastri, M. N., Sundar, D. S. : Anal. Chim. Acta 33, 340 (1965)

10. Tuck, D. G.: Anal. Chim. Acta 27, 296 (1962)

11. Upadhyay, B., Upadhyay, A., Tripathi, S. C.: J. Indian Chem. Soc. 54, 431 (1977)

Received May 20, 1980 